Sains Malaysiana 47(1)(2018): 9-18

http://dx.doi.org/10.17576/jsm-2018-4701-02

\title{
An Epidemiological Study on Endoparasites of Domestic Rabbits (Oryctolagus cuniculus) in Egypt with Special Reference to Their Health Impact \\ (Kajian Epidemiologi pada Endoparasit Arnab Domestik (Oryctolagus cuniculus) di Mesir dengan Rujukan Istimewa kepada Kesan ke atas Kesihatan Mereka)
}

ISMAIL ELSHAHAWY* \& ASHRAF ELGONIEMY

\begin{abstract}
The present study was designed to study the enteric parasites infection in domestic rabbits in Upper Egypt and its impact on their health. A total of 298 faecal samples were collected from different farms in Upper Egypt. Each faecal sample was screened for parasitic isolation during May 2011-October 2012. Furthermore, The Eimeria species from samples containing isolated and sporulated oocysts were morphologically identified under microscope. Additionally, the Sheather's sugar flotation and Modified Zeihl Neelsen techniques were used to detect the Cryptosporidium species oocyst. According to results of the present study, the overall enteric parasite infections in rabbits was $68.12 \%$, with $5.7 \%$ samples were found to be positive for helminths (P. ambiguus) and $49 \%$ were found to harbour various species of protozoa (Eimeria spp. and Cryptosporidium oocysts). Influences of age, sex and breed on the prevalence were recorded. Also, there was strong significant seasonal trends in the prevalence of the recovered parasites. Eight species of Eimeria were detected. Concurrent infection with two to eight Eimeria species occurred most frequently. Cryptosporidium oocyst was detected in 45 rabbits (15.1\%). To the best of author's knowledge, this the first report of E. piriformis and Cryptosporidium species in rabbits in Egypt. Histopathological changes were indicative of inflammatory reactions brought about by parasitic infection with Eimeria species and its consequent irritating effects on intestine. The current study showed the characteristics of the prevalence of rabbit enteric parasite infection in Egypt and provided relevant 'baseline' data for assessing the effectiveness of future control strategies against these parasites in Egypt.
\end{abstract}

Keywords: Egypt; helminth; pathology; prevalence; protozoa; rabbits

ABSTRAK

Penyelidikan ini telah dijalankan untuk mengkaji jangkitan parasit enteron pada arnab domestik di Mesir Atas dan kesannya ke atas kesihatan mereka. Sebanyak 298 sampel tinja telah diambil dari ladang yang berlainan di Mesir Atas. Setiap sampel tinja ini telah disaring untuk pengasingan parasit sepanjang Mei 2011-Oktober 2012. Selain itu, spesies Eimeria daripada sampel yang mengandungi oosista yang dipencil dan disporulat secara morfologi telah dikenal pasti di bawah mikroskop. Di samping itu, pengapungan gula Sheather dan teknik ubah suai Zeihl Neelsen telah digunakan untuk mengesan oosista spesies Cryptosporidium. Menurut keputusan kajian ini, jangkitan keseluruhan parasit enteron dalam arnab adalah $68.12 \%$ dengan 5.7\% daripada sampel didapati positif untuk helmint (P. ambiguus) dan 49\% didapati mempunyai pelbagai spesies protozoa (Eimeria spp. dan Cryptosporidium oosista). Pengaruh umur, jantina dan baka secara lazim telah direkodkan. Selain itu, terdapat pengaruh aliran musim secara lazim bagi parasit yang diambil. Lapan spesies Eimeria telah dikesan. Jangkitan serentak dengan dua hingga lapan spesies Eimeria berlaku paling kerap. Oosista Cryptosporidium dikesan pada 45 arnab (15.1\%). Sepanjang pengetahuan penulis, ini merupakan laporan pertama E. piriformis dan spesies Cryptosporidium pada arnab di Mesir. Perubahan patologi menunjukkan tindak balas keradangan yang disebabkan oleh jangkitan parasit dengan spesies Eimeria dan kesannya merengsa pada usus. Kajian ini menunjukkan ciri kelaziman jangkitan parasit enteron pada arnab di Mesir dan menyediakan data 'garis dasar' untuk menilai keberkesanan strategi masa hadapan terhadap kawalan parasit di Mesir.

Kata kunci: Arnab; helmint; kelaziman; Mesir; patologi; protozoa

\section{INTRODUCTION}

In recent years, rabbit production became well established in Egypt. Most of the rabbit population in Egypt is in the hands of small holders, while the rest belongs to the commercial sector as a good source of protein (Lebdah \& Shahn 2011). In addition to this commercial value, they are also used for the diagnosis of infectious diseases, in the production of vaccines and other biological substances of public health and veterinary importance (Harcourt 2002). Intestinal parasites, both protozoa and helminths, are one of the main enteropathogen of rabbits, especially in neonates. Some of these parasites are responsible for direct and indirect losses that are attributed to acute illness and death, premature slaughter and diminution of productive 
potential such as decreased growth rate, weight loss and late maturity of slaughter stock (Hansen \& Perry 1994), as well as to important zoonotic emerging and re-emerging infections, such as cryptosporidiosis.

Passalurus ambiguus infections of rabbit are not generally thought to be very pathogenic, although fatal massive infections in young rabbits have been recorded (Eira et al. 2007).

Coccidiosis of rabbits are ubiquitous infections caused by obligatory intracellular protozoan parasites belonging to the genus Eimeria and considered as a major cause of significant morbidity and mortality (Bhat et al. 1996). Although mortality can result from heavy infection by these parasites, the majority of infections result in morbidity due to lower weight gain and diarrhea (Renaux et al. 2003).

Cryptosporidium is a ubiquitous enteropathogen and has been reported from many geographical regions of the world. Although the first report of rabbit Cryptosporidium was noticed in 1912 (Tyzzer 1912), the concerns regarding Cryptosporidium infection in rabbits have only occurred in recent years due to a few sporadic human cases and a serious waterborne outbreak of cryptosporidiosis caused by Cryptosporidium cuniculus (previously named as Cryptosporidium rabbit genotype) (Chalmers et al. 2009; Molloy et al. 2010; Robinson et al. 2008).

Despite the importance of rabbits as good source of animal protein in Egypt, very few parasitological studies of enteric parasite infection in rabbits have been done (Abdel Megeed et al. 2005; Abu-Akkada et al. 2010; Arafa \& Wanas 1996; Atta et al. 1999). Since the knowledge on rabbit enteric parasite is rather scarce, the present study was undertaken. The present study deals with the basic epidemiological survey of natural prevalence of enteric parasite infections among rabbits, which will facilitate the establishment of an efficient control system for rabbit parasites in Egypt.

\section{MATERIALS AND METHODS}

\section{ANIMALS AND PARASITOLOGICAL TECHNIQUES}

In the present study, 298 rabbits Oryctolagus cuniculus of both sexes, different age groups and breeds randomly collected from different localities in Upper Egypt (small farmers, private and Governmental rabbitries), Egypt were investigated. Fresh faecal samples were screened for enteric parasite infections.

The studied rabbits were housed in galvanized wire cages ( $40 \mathrm{~cm}$ high $\times 50 \mathrm{~cm}$ width $\times 60 \mathrm{~cm}$ length) and fresh water was automatically available at all time. These rabbits were fed with commercial standard rabbit diet without any anti-parasitic or anti-coccidian drugs prior to sampling.

For detection of helminth and coccidian infections, concentration floatation technique was performed as each faecal sample was homogenized in $100 \mathrm{~mL}$ tap water, and then $2 \mathrm{~g}$ of the mixture was put into $60 \mathrm{~mL}$ of saturated salt solution (Carvalho et al. 2011). Furthermore, the suspension was then emptied into a modified McMaster chamber (Coudert et al. 1995). Five min later, the oocysts within the chamber were counted under the microscope and the oocyst per gram (OPG) was calculated to estimate the degree of infection. Additionally, the Sheather's sugar flotation and Modified Zeihl Neelsen techniques were used to detect the Cryptosporidium species oocysts (Henriksen \& Pholenz 1981).

\section{SPECIES IDENTIFICATION}

Oocysts of Eimeria species were purified as previously described by Kvičerová et al. (2008) and were sporulated by shaking in a $2.5 \%$ potassium dichromate solution at $25 \pm 3^{\circ} \mathrm{C}$ for 7 days to ensure good aeration and stored at $4^{\circ} \mathrm{C}$ until morphological identification at laboratory of Parasitology- Faculty of Veterinary Medicine, Quena, South Valley University. Concentrated oocysts in each sample were identified based on their sizes and morphological characteristics (shape, colour, form index, presence or absence of the micropyle and its cap, presence or absence of residual, polar and Stieda bodies) of the oocysts and sporocysts (Kvičerová et al. 2008). To ensure that species identification is valid, at least 50 sporulated oocysts from each species were observed and measured. Additionally, the Cryptosporidium oocyst appeared red on green background in the examined fecal smears.

\section{POST MORTEM AND HISTOPATHOLOGICAL EXAMINATIONS}

Furthermore, post mortem examination was carried out on 40 dead rabbits. The obtained material was evaluated through macroscopic analysis of each liver and gall bladder and inspected for nodules typical characteristic of infection with Eimeria stiedae followed by liver smear treatment (Sivajothi et al. 2014). Histopathologically, intestines of the dead rabbits were thoroughly examined for the gross lesions and specimens were collected in $10 \%$ formalin. Tissues were processed as per standard technique and 5-6 $\mu \mathrm{m}$ thick paraffin embedded sections were cut for histopathological examinations after staining with H. \& E. (Carlton \& McGavin 1995).

\section{STATISTICAL ANALYSIS}

The significance of differences was analyzed using chisquare $(\chi 2)$ using the Statistical Package for Social Science version 15.0 (SPSS Inc., Chicago, IL) and $p<0.05$ was considered significant.

\section{RESULTS}

\section{SURVEY RESULTS}

As shown by the preliminary coproscopic survey, the overall enteric parasite infections in the present investigation was $68.12 \%$ with $5.7 \%$ samples were found to be positive for helminths and $49 \%$ were found to harbour various species of protozoa as depicted in Table 1 . 
TABLE 1. Prevalence of parasitic infections in rabbits, found by faecal examination

\begin{tabular}{|c|c|c|c|c|c|c|c|c|c|c|}
\hline \multirow{3}{*}{$\begin{array}{c}\text { Total no. of } \\
\text { examined } \\
\text { rabbits }\end{array}$} & \multicolumn{6}{|c|}{ Enteric parasites } & \multirow{3}{*}{\multicolumn{2}{|c|}{ Mixed infection }} & \multirow{3}{*}{\multicolumn{2}{|c|}{ Total }} \\
\hline & \multirow{2}{*}{\multicolumn{2}{|c|}{ Helminth eggs }} & \multicolumn{4}{|c|}{ Protozoa } & & & & \\
\hline & & & Eimer & pp. & Cryptospo & $n$ spp. & & & & \\
\hline \multirow[t]{2}{*}{298} & $\begin{array}{c}\text { No. of } \\
\text { infected } \\
\text { cases }\end{array}$ & $\%$ & $\begin{array}{c}\text { No. of } \\
\text { infected } \\
\text { cases }\end{array}$ & $\%$ & $\begin{array}{c}\text { No. of } \\
\text { infected } \\
\text { cases }\end{array}$ & $\%$ & $\begin{array}{c}\text { No. of } \\
\text { infected } \\
\text { cases }\end{array}$ & $\%$ & $\begin{array}{c}\text { Total no. } \\
\text { of infected } \\
\text { cases }\end{array}$ & $\%$ \\
\hline & 17 & 5.7 & 101 & 33.9 & 45 & 15.1 & 40 & 13.4 & 203 & 68.12 \\
\hline
\end{tabular}

Coproscopic analysis showed that the studied rabbits were infected with different parasite species including one nematode and two protozoan parasites.

Among the protozoan; the coccidia identified were Eimeria spp. and Cryptosporidium spp., while the identified helminths were Passalurus ambiguus.

With regard to protozoan parasites, the same table displayed that Eimeria species were the most prevalent species with an infection rate of $33.9 \%$, while Cryptosporidium spp. was represented in $15.1 \%$ of the observed samples. Additionally, the mean Eimiria oocyst count was 20380oocysts/g, while the oocyst load of Cryptosporidium spp. was very minimal since the smears showed 2oocysts /slide.

Through this study, eight species of Eimeria, namely Eimeria media, E. intestinalis, Eimeria coecicola, E. magna, Eimeria exigua, Eimeria perforans Eimeria flavescens and E.piriformis, were identified from naturally infected rabbits in Egypt with the later species was recognized and described for the first time in Upper Egypt.

$E$. perforans and E. magna were generally the most predominant species, while, E. media, E. coecicola $E$. flavescence, and E. exigua were less common and $E$. intestinalis and E. piriformis were relatively rare as illustrated in Table 5).

Concurrent infections with more than one Eimeria species were commonly recorded in rabbits. Most of the rabbits in the present study carried two to eight species. The percentages of single and mixed infections of different Eimeria species in rabbits were shown in Figure 1.
Influence of age, sex and breed on the prevalence of Eimeria infection in rabbits was shown in Tables 2 and 3 . From these tables it was evident that the prevalence of coccidian oocysts in young rabbits $(47.1 \%)$ was higher than in adult rabbits $(3.3 \%)$ and the differences were statistically significant $(p<0.05)$. Additionally, the prevalence was significantly higher in female rabbits $(45 \%)$ compared to the male $(2.7 \%)$, which is consistent with previous observations. On the other hand, coccidian oocysts were found in $48.5 \%(98 / 202)$ of faecal samples from Newzeland rabbits, $9.1 \%$ (1/11) from English rabbits and $7.7 \%$ (2/26) from Rex rabbits; with no infections among the other breeds; these values were significantly different $(p<0.05)$.

Seasonally, the prevalence was highest in winter $(63.3 \%)$, particularly during rainfall months, followed by spring and autumn seasons where the infection rates were $40 \% \%$ and $33 \% \%$ respectively, while the least was recorded during summer season (6\%) (Table 4).This marked difference was found to be statistically significant $(\chi 2=53.57)$.

The results of the present study showed that E. stiedae, the causative agent of hepatic coccidiosis and one of the most important and well-known species of Eimeria in rabbits was not found in this area.

In respect to Cryptosporidium species, forty five samples were found to be positive for C.cuniculus $(15.1 \%)$, adult were found more often infected ( 26 out of 90,28.9\%) than kitten rabbit (19 out of $208,9.1 \%$ ) and the difference was statistically significant. Additionally, the prevalence

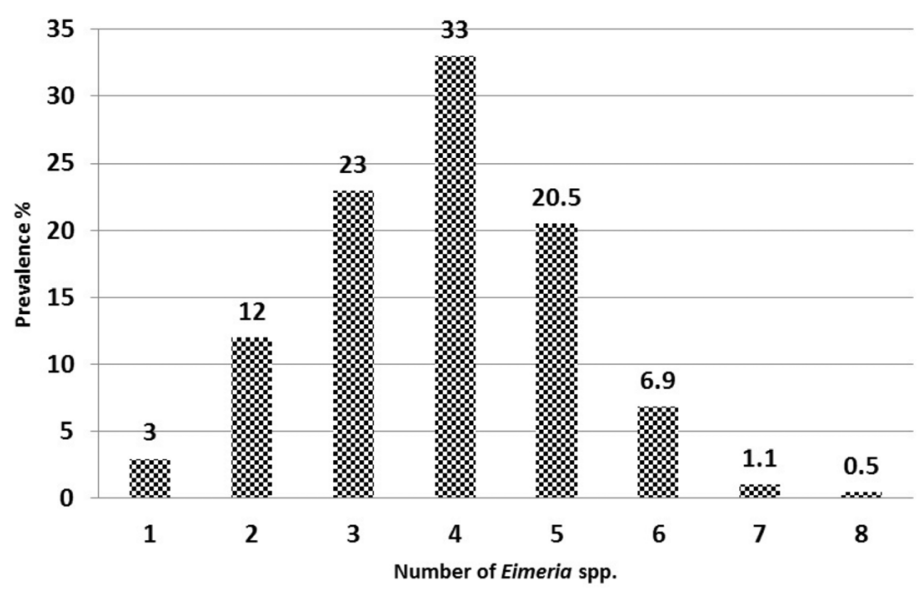

FIGURE 1. Frequencies of Eimeria species isolated from infected rabbits 
TABLE 2. Prevalence of parasitic infections in rabbits, distributed by age and sex

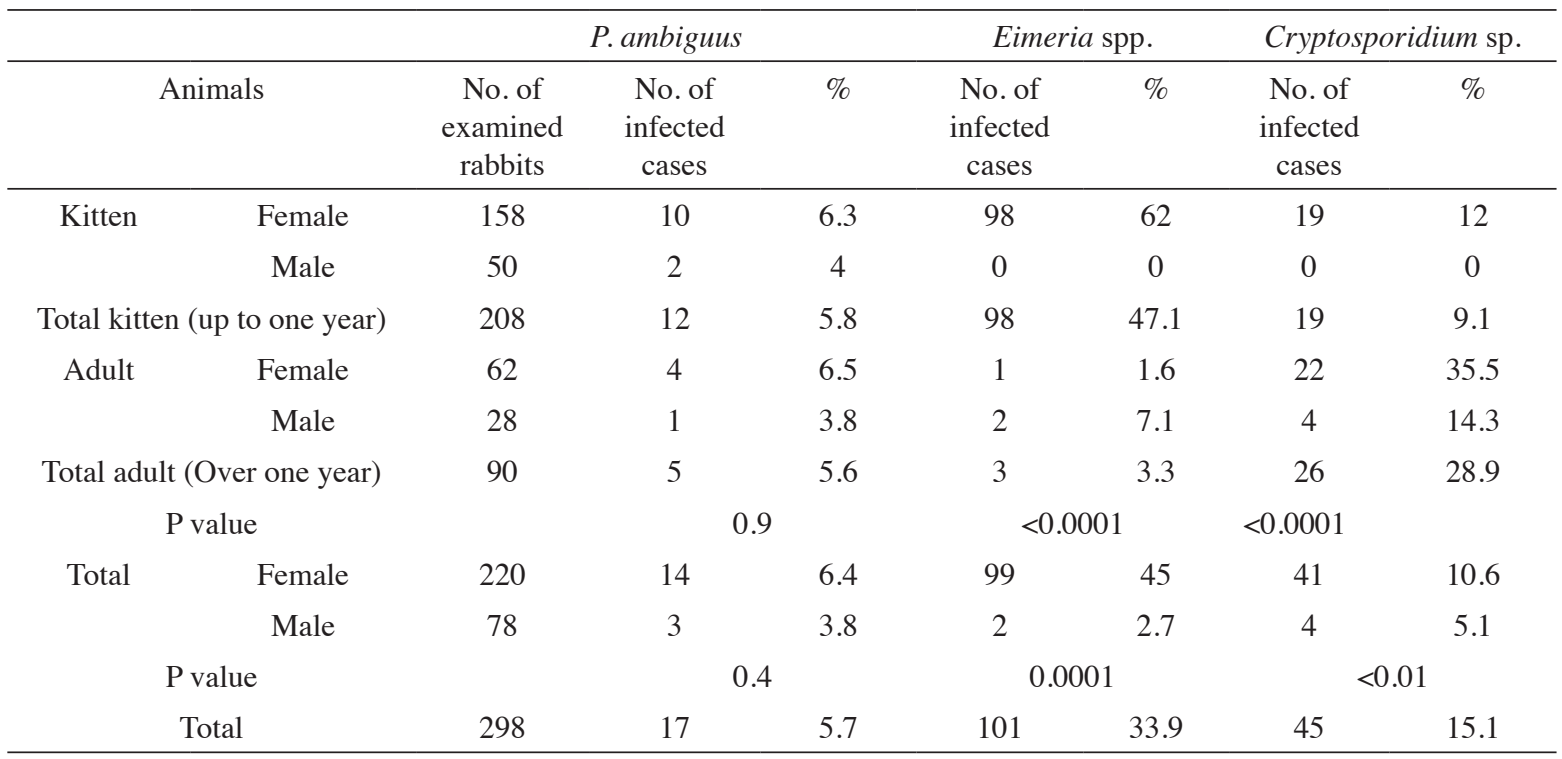

TABLE 3. Prevalence of enteric parasites infection in different rabbit breeds

\begin{tabular}{|c|c|c|c|c|c|c|c|}
\hline \multirow[b]{2}{*}{ Rabbits breeds } & \multicolumn{3}{|c|}{ P. ambiguus } & \multicolumn{2}{|c|}{ Eimeria spp. } & \multicolumn{2}{|c|}{ Cryptosporidium sp. } \\
\hline & $\begin{array}{l}\text { No. of } \\
\text { examined } \\
\text { rabbits }\end{array}$ & $\begin{array}{l}\text { No. of } \\
\text { infected } \\
\text { rabbits }\end{array}$ & $\%$ & $\begin{array}{l}\text { No. of } \\
\text { infected } \\
\text { rabbits }\end{array}$ & $\%$ & $\begin{array}{l}\text { No. of } \\
\text { infected } \\
\text { rabbits }\end{array}$ & $\%$ \\
\hline English sp. & 11 & 1 & 9.1 & 1 & 9.1 & 1 & 9.1 \\
\hline Babion sp. & 13 & 0 & 0 & 0 & 0 & 3 & 23.1 \\
\hline Newzeland sp. & 202 & 3 & 14.9 & 98 & 48.5 & 21 & 10.4 \\
\hline Flander sp. & 4 & 0 & 0 & 0 & 0 & 1 & 25 \\
\hline Rex sp. & 26 & 4 & 15.4 & 2 & 7.7 & 4 & 15.4 \\
\hline Belgicie sp. & 11 & 3 & 27.3 & 0 & 0 & 3 & 27.3 \\
\hline Shenshella sp. & 11 & 1 & 9.1 & 0 & 0 & 3 & 27.3 \\
\hline California sp. & 20 & 5 & 25 & 0 & 0 & 9 & 45 \\
\hline$P$ value & & \multicolumn{2}{|c|}{$<0.0005$} & \multicolumn{2}{|c|}{$<0.0001$} & \multicolumn{2}{|c|}{0.0005} \\
\hline Total & 298 & 17 & 5.7 & 101 & 33.9 & 45 & 15.1 \\
\hline
\end{tabular}

was significantly higher in female rabbits $(10.6 \%)$ compared to the male $(5.1 \%)$. On the other hand, Cryptosporidium oocysts were found in $45 \%(9 / 20)$ of faecal samples from California rabbits, $27.3 \%$ (3/11), from English rabbits and $25 \%$ (1/4) from Flander rabbits; with variable rates ranging from $9.1 \%-23.1 \%$ among the other examined breeds; these values were found to be significantly different $(p<0.05)$ as recorded in Tables 2 and 3.

Seasonally, from the samples collected, Cryptosporidium oocyst was more prevalent in the summer season $(24.1 \%)$, followed by autumn and spring where the infection rates were $15 \%$ and $11.6 \%$, respectively, while the lowest rate was in winter $(8.3 \%)$. This marked difference was found to be statistically significant $(\chi 2=$ 8.3) (Table 4).

A nematode, Passalurus ambiguus, was detected in 17 out of 298 of the examined samples with an overall infection rate of $5.7 \%$. Younger animals tend to be susceptible to helminthiasis as compared to adults. However, these differences were not significant $(p>0.05)$. In addition; relatively higher prevalence of helminthiasis was observed in female animals $(6.4 \%)$ compared to male $(3.8 \%)$ but the difference was not significant $(p>0.05)$ as indicated in Table (2).

In regard to rabbit breed, the most susceptible to helminth infections seem to be Belgicie rabbits (27.3\%) and the least susceptible English and Babion rabbits (9.1\%). This marked difference was found to be statistically significant $(\chi 2=22.4)$ Table (3)

Seasonally, the main feature was a peak incidence of P. ambiguus during summer (16.9\%) followed by a gradual fall in spring (3.2\%); with no observed infection in winter and autumn seasons. These differences were found to be significant $(p<0.05)$ as depicted in Table (4). 
TABLE 4. Seasonal prevalence of parasitic infections in rabbits, found by faecal examination

\begin{tabular}{|c|c|c|c|c|c|c|}
\hline \multirow{4}{*}{ Season } & \multicolumn{6}{|c|}{ Internal parasites } \\
\hline & \multirow{2}{*}{\multicolumn{2}{|c|}{ P. ambiguus eggs }} & \multicolumn{4}{|c|}{ Protozoa } \\
\hline & & & \multicolumn{2}{|c|}{ Eimeria spp. } & \multicolumn{2}{|c|}{ Cryptosporidium spp } \\
\hline & $\begin{array}{c}\text { No. of } \\
\text { infected cases }\end{array}$ & $\%$ & $\begin{array}{c}\text { No. of infected } \\
\text { cases }\end{array}$ & $\%$ & $\begin{array}{c}\text { No. of infected } \\
\text { cases }\end{array}$ & $\%$ \\
\hline winter $(n=60)$ & 0 & 0 & 38 & 63.3 & 5 & 8 \\
\hline spring $(n=95)$ & 3 & 3.2 & 38 & 40 & 11 & 11.6 \\
\hline summer $(n=83)$ & 14 & 16.9 & 5 & 6 & 20 & 24.1 \\
\hline autumn $(n=60)$ & 0 & 0 & 20 & 33 & 9 & 15 \\
\hline$P$ value & \multicolumn{2}{|c|}{$<0.0001$} & \multicolumn{2}{|c|}{$<0.0001$} & \multicolumn{2}{|c|}{$<0.05$} \\
\hline
\end{tabular}

TABLE 5. Percentage of faecal samples infected with each coccidia species in rabbits

\begin{tabular}{|c|c|c|c|c|c|c|c|c|c|c|}
\hline \multirow[t]{2}{*}{$\begin{array}{c}\text { Eimeria } \\
\text { species }\end{array}$} & \multicolumn{2}{|c|}{$\begin{array}{l}\text { Rabbit kitten } \\
\text { up to one year } \\
\text { No }=70\end{array}$} & \multicolumn{2}{|c|}{$\begin{array}{l}\text { Adult rabbits } \\
\text { More than one year } \\
\text { No }=30\end{array}$} & \multicolumn{2}{|c|}{$\begin{array}{c}\text { Doe } \\
\text { No }=72\end{array}$} & \multicolumn{2}{|c|}{$\begin{array}{c}\text { Buck } \\
\text { No }=28\end{array}$} & \multicolumn{2}{|c|}{$\begin{array}{c}\text { Total } \\
\text { No }=100\end{array}$} \\
\hline & No & $\%$ & No & $\%$ & No & $\%$ & No & $\%$ & No & $\%$ \\
\hline E.perforans & 67 & 95.7 & 5 & 16.7 & 67 & 93.1 & 5 & 17.9 & 72 & 72 \\
\hline E. magna & 62 & 88.6 & 6 & 20 & 6 & 88.6 & 62 & 21.4 & 68 & 68 \\
\hline E.flavescens & 38 & 54.3 & 6 & 20 & 38 & 52.8 & 6 & 21.4 & 44 & 44 \\
\hline E. coecicola & 30 & 42.9 & 6 & 20 & 30 & 41.7 & 6 & 21.4 & 36 & 36 \\
\hline E. exigua & 25 & 35.7 & 0 & 0 & 25 & 34.7 & 0 & 0 & 25 & 25 \\
\hline E. media & 20 & 28.6 & 0 & 0 & 20 & 27.8 & 0 & 0 & 20 & 20 \\
\hline E. intestinalis & 10 & 14.3 & 2 & 6.7 & 10 & 13.9 & 2 & 7.1 & 12 & 12 \\
\hline E. piriformis & 6 & 8.6 & 2 & 6.7 & 6 & 8 & 2 & 7.1 & 8 & 8 \\
\hline
\end{tabular}

\section{MORPHOLOGICAL FEATURES OF THE RECOVERED} ENTERIC PARASITES

The most common features of the recovered enteric parasites were summarized as illustrated in Table 6 and Figure 2.

\section{HISTOPATHOLOGICAL RESULTS}

Macroscopically Intestines of naturally infected rabbits appeared pale in color, atrophied with extensive degree of the congestion, hemorrhagic with ulcerative wall and there was a mass of clotted blood in the intestinal lumen (Figure

TABLE 6. Morphological characteristics of sporulated Eimeria species from rabbits

\begin{tabular}{|c|c|c|c|c|c|c|c|c|c|}
\hline \multirow{2}{*}{ 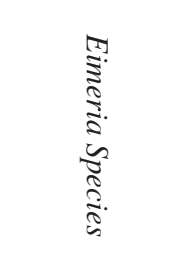 } & \multirow{2}{*}{ 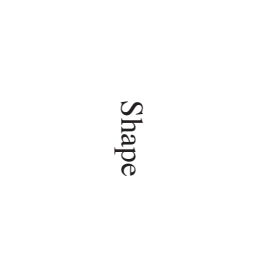 } & \multicolumn{2}{|c|}{ Mean oocyst size } & \multirow{2}{*}{ 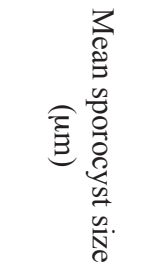 } & \multirow{2}{*}{ ஜ } & \multirow{2}{*}{$\begin{array}{l}3 \\
\frac{3}{0} \\
\frac{0}{0} \\
\frac{0}{0} \\
0\end{array}$} & \multirow{2}{*}{ 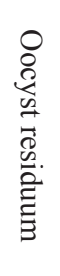 } & \multirow{2}{*}{ 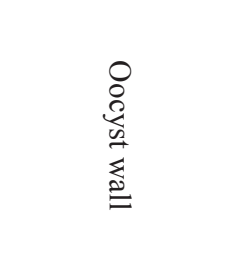 } & \multirow{2}{*}{ 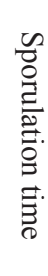 } \\
\hline & & $\begin{array}{c}\text { Length } \\
(\mu \mathrm{m})\end{array}$ & $\begin{array}{l}\text { Width } \\
(\mu \mathrm{m})\end{array}$ & & & & & & \\
\hline E. piriformis & Ellipsoid & 27.87 & 17.97 & $9.85 \times 7.14$ & - & + & - & Yellowish & 36 \\
\hline E. coecicola & Elongated ellipsoid & 30.52 & 17.56 & $17.47 \times 9.88$ & - & + & + & Yellowish green & 62 \\
\hline E. flavescens & Ovoid & 29.22 & 16.70 & $12.98 \times 6.78$ & - & + & - & Yellowish brown & 56 \\
\hline E. exigua & Spherical & 15.83 & 15.83 & $7.97 \times 6.17$ & - & - & - & Purple & 28 \\
\hline E. intestinalis & Pyriform & 28.29 & 17.08 & $12.03 \times 6.04$ & - & + & + & Greenish brown & 55 \\
\hline E. perforans & Ovoid & 22.16 & 14.45 & $10.57 \times 7.76$ & - & - & + & Greenish & 36 \\
\hline E. media & Ovoid to ellipsoid & 28.64 & 16.70 & $12.17 \times 7.34$ & - & + & + & Light pink & 36 \\
\hline E.magna & Ovoid & 36.80 & 23.53 & $13.41 \times 7.21$ & - & + & + & Yellowish brown & 52 \\
\hline
\end{tabular}


3(A)). Moreover, diarrhea was reported in $50(16.8 \%)$ of rabbits and it was indicated by matted perineum, the presence of watery, mucoid and abnormally soft feces as shown in Figure $(2(\mathrm{~S}) \& 2(\mathrm{~T}))$.

Microscopically Intestines of naturally infected rabbits had characteristic lesions manifested by severe degree of necrosis of the intestinal cells characterized by pyknotic and tiny nuclei with acidophilic cytoplasm were detected along intestinal tissues. Sloughing with desquamation of the epithelial lining at the lumen was observed. Moreover, atrophy of intestinal villi was noticed as well as different developmental stages of Eimeria spp. were noticed in crypts (Figure 3(B), 3(C), 3(D), 3(E) \& 3(F)).

\section{DISCUSSION}

Parasitic infections pose a serious health threat and limit the productivity of livestock due to the associated morbidity and mortality. More specifically, plethora of parasitic diseases plays a detrimental role in rabbit's production leading to serious economic loss. Therefore, Knowledge of prevalence of enteric parasites and current species will help to minimize the economic losses in the rabbit industry, evaluate infection potential and control programs, especially for kits (Nwosu et al. 2007).

This study has provided for the first time detailed quantitative data on infections with enteric parasites in rabbits, which is relatively poorly studied and about which little is known.

The percentage of rabbit that bear one or more parasitic species in the present study was high $(68.12 \%)$. The most prevalent parasites found were Eimeria spp. (33.9\%). Similar patterns were reported in other previous studies on rabbits (Biu \& Nwosu 1998; Gurpartap \& Khahra 1997). On the contrary, the prevalence rates were relatively higher than that previously recorded in Thrissur as the prevalence of coccidial infection in rabbits was $18.54 \%$ (Shameem \& Devada 2005). These variations were likely due to wide usage of grass, silage and grain as rabbit diet, making the administration of anticoccidials in feed impracticable in small farms, although practice other than anticoccidials was also employed in rabbit farming, poor hygienic conditions and suboptimal temperatures were observed on some small individual rabbit farms, which can favour the occurrence of Eimeria spp. Infections.

Additionally, the present finding was lower than that reported among the European, Indian, Turkish and Taiwanese rabbits in previous studies as the overall prevalence of the coccidial infections in rabbits were $60 \%$, $64 \%, 80 \%$ and $41.7 \%$, respectively (Chandra \& Ghosh 1990; Gonzalez-Redondo et al. 2008; Karaer 2001; Li et al. 2010). Variations in the percentage frequency of occurrence of coccidial infections worldwide are expected and this may be attributed to various factors, including the difference in environmental conditions prevailing in each region, meteorology and agro-ecology.

According to the accessible literature, the study of rabbit Eimeria in Egypt is very limited. Most of these studies were concerned with histopathology, biochemistry, and treatment of the hepatic coccidiosis, and they were done mostly with E. stiedai (Abdel Megeed et al. 2005; Abu-Akkada et al. 2010). In the present study, eight
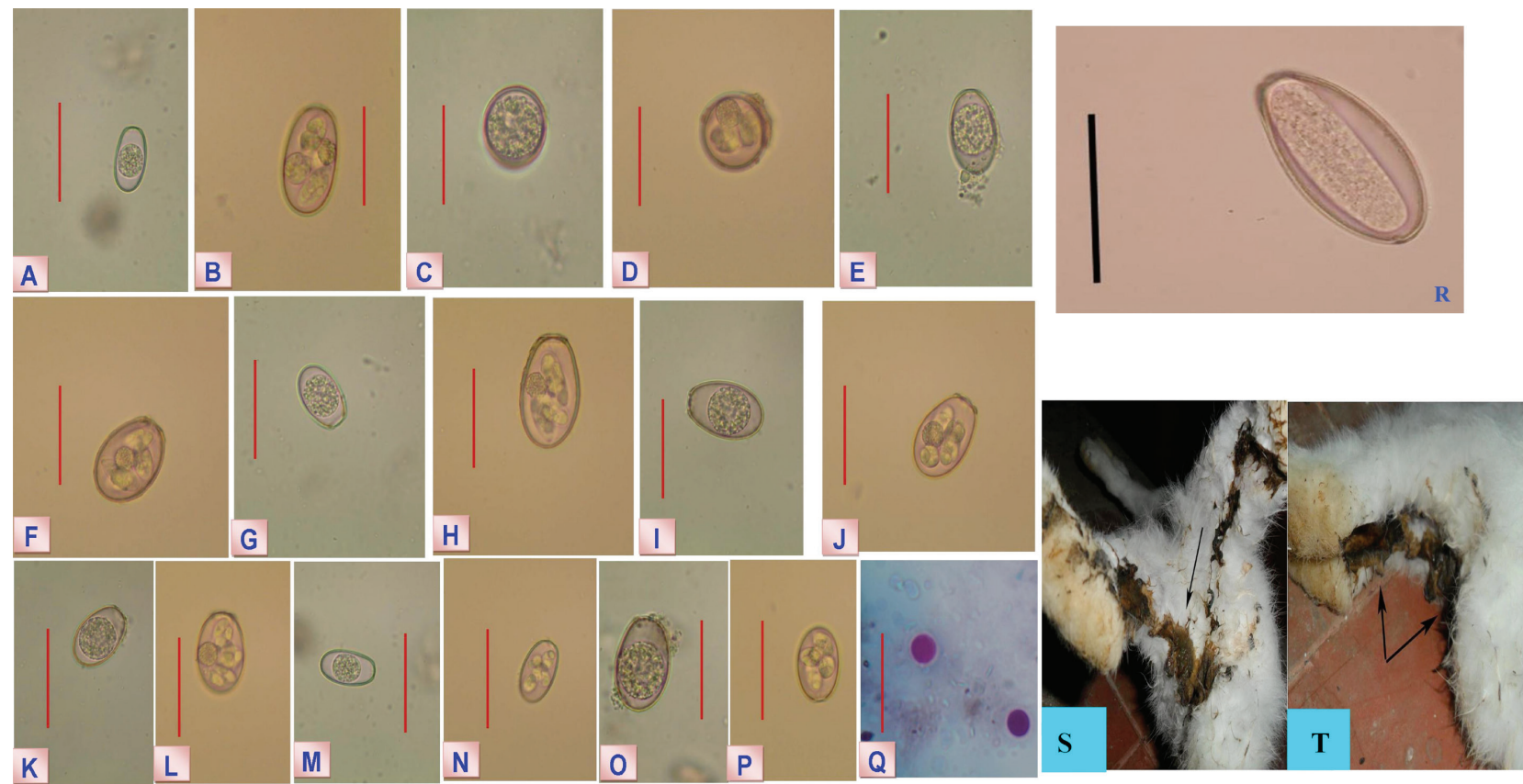

FIGURE 2. (A-Q) Coccidia species in rabbits $(\mathrm{Bar}=20 \mu \mathrm{m})$; A\&B: E. coecicola, C\&D: E. exigua, E\&F: E. flavescence, G\&H: E. intestinalis, I\& J: E. magna, K\&L: E. media, M\&N: E. perforans, O\&P: E. piriformis and Q: Cryptosporidium oocyst $(\mathrm{Bar}=50 \mu \mathrm{m}) .(\mathrm{R})$ Helminth parasite stages identified, Passalurus ambiguus egg $(\mathrm{Bar}=20 \mu \mathrm{m})$, Rabbits with severe diarrhea due to intestinal coccidiosis (S \&T) (arrow) 


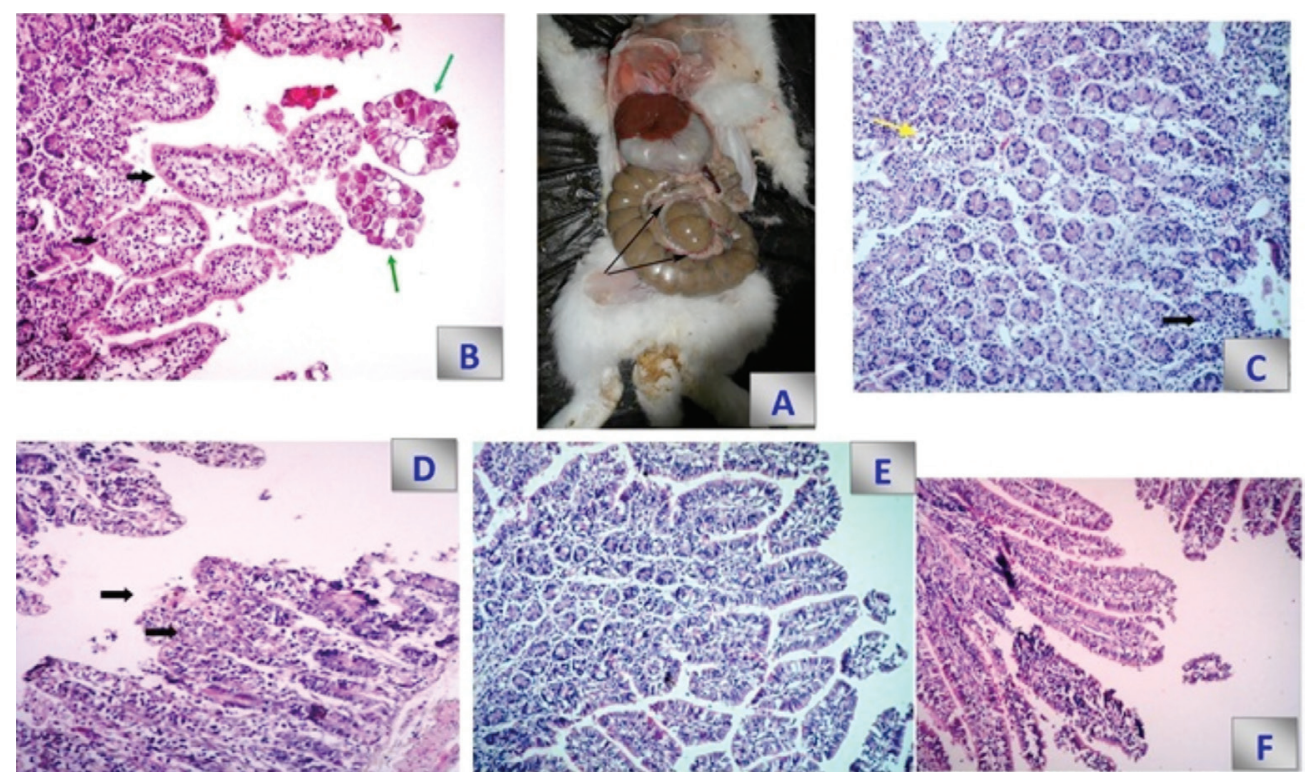

FIGURE 3. Intestines of naturally infected rabbit with Eimeria spp

A: showing congestion with thickened, hemorrhagic, ulcerated wall, B: Intestine showing necrosis of the cells with sloughing and desquamation of the intestinal lining (black arrow) and different developmental stages of Eimeria spp. (green arrow). C: Intestine showing severe inflammatory cells infiltration mainly lymphocytes (arrows), D, E \& F: Intestine showing mild degree of sloughing of the epithelium lining, besides mild degree of lymphocytes infiltration (H\&E $\times 40)$.

species were recognized, of which 7 species was recorded previously (El-Shahawi et al. 2012) and one additional species E. piriformis was recognized and described for the first time in Egypt. Our descriptions of the sporulated oocysts of Eimeria from rabbits in Egypt vary slightly in size and other negligible characteristics from previous descriptions (El-Shahawi et al. 2012; Razavi et al. 2010). From different Eimeria species present in the rabbits of the present study, some species including E. flavescens and $E$. intestinalis are regarded as highly pathogenic organisms and may have led to hemorrhagic enteritis in rabbits ( $\mathrm{Li}$ \& Ooi 2009).

The influences of age, sex and breeds were also taken into consideration in the current study. Lower resistance or less immunity to coccidian infection in young rabbits than in older animals (Pakandl et al. 2008) is responsible for the high prevalence of coccidiosis in young rabbits (47.1\%). Additionally, host sex exercise a great significant influence on parasitation, as females harbored more infection compared to males, agreeing with various studies having reported this parasite in rabbits (Abdel-Baki \& Al-Quraishy 2013).

Mixed infection with four Eimeria species was most frequent in the present study and in all previous studies as natural infection with a single Eimeria species are rare (Yakhchali \& Tehrani 2007). These results could be attributed to that healthy rabbit could support the heavy infection with mixed species but stress factors encourage the onset of the disease, or likely due to the nature of the pasture which usually contaminated by various kind of parasites.

Referring to the influence of the season, with highest prevalence in winter season $(63.3 \%)$ and the lowest was in summer $(6 \%)$. This indicated that favorable humidity and temperature hastened sporulation. Also the increase of infection was reported in areas of high humidity and rainfall (Rajkhowa 1996). Oocysts survive best in shaded moist condition with proper moisture and warmth condition (Soulsby 1986). Significant seasonal differences observed might be due management care, types of diet offered to the rabbits under the study.

In respect to the absence of E. stiedae in the present investigation, similar observation was reported previously in USA, France and Saudi Arabia, respectively (Al-Mathal 2008; Al-Rukibat et al. 2001; Gres et al. 2003).

In respect to Cryptosporidium, although Cryptosporidium was subsequently found in a broad range of animals, its impact was neglected until the early 1980s when it was found to be a common, serious primary cause of outbreaks of diarrhea in farm mammals (Angus et al. 1982). This is the first report of Cryptosporidium infection in pet rabbit in Upper Egypt area. Furthermore, the overall prevalence of Cryptosporidium in the present investigation was $15.1 \%$. Similar results were reported in Japan, in a study of Cryptosporidium infection in juvenile pet rabbits, where the prevalence was $16.7 \%$ (Shiibashi et al. 2006). The result of this study thus implies that Cryptosporidium infection in rabbit, as well as the possible risk of transmission to humans by rabbit, is important in Egypt as it is elsewhere in the world. Hence, considerable attention should be paid to preventing the spread of the infection.

Our findings showed that there was significant difference $(p>0.05)$ between the rate of the infection in rabbit and the age, with highest peaks in adult $(28.9 \%)$ compared to young rabbits $(9.1 \%)$. Similar results have 
been observed in pigs that the percentage of pigs shedding Cryptosporidium oocysts increased as the pigs got older (Morgan et al. 1999). This suggests that maternal antibodies protect animals from developing infections. On the contrary, the present data was not in line with that reported previously, as the age played an important role in the incidence of Cryptosporidium infection as young's more susceptible to infection with Cryptosporidium (Ohaeri \& Iwu 2003).

The present study also reports a significant difference $(p<0.0001)$ between the infection rates of Cryptosporidium sp. in female and male rabbit, with the female animals twice as likely to be at risk as the males. The reason for this disparity is not known, although this outcome could be attributed to the usual practice of having a higher female: Male ratio in a farm and also the retention of female animals for breeding. It could also be related to host intrinsic factors (genetics, physiology and immunology) and extrinsic factors (environment and management practices) (De Graaf et al. 1999).

The findings of the present study showed that seasons have a significant effect on the prevalence of infection in rabbits, with highest prevalence in summer $(24.1 \%)$ followed by autumn and spring (15\% and $11.6 \%$, respectively) and lowest in winter $(8 \%)$. Peaks in Cryptosporidium prevalence appear to correspond with warmer seasons in temperate and tropical climates (Bern et al. 2002).

The present study showed the overall prevalence of the recovered helminths, P. ambiguus to be $5.7 \%$. This result was very close to the report on helminths prevalence in rabbit's in Jeonbuk area (Tae-Wook et al. 2003) and relatively higher than the previous findings in Turkey (Sürsal et al. 2014). However, the prevalence rates were relatively lower than that recorded previously in eastern Scotland (14.2\%) (Boag 1985) and in Egypt (26.7\%) (Ashmawy et al. 2010). These variations were likely to be due to difference in environmental condition, mangemental care, nature of pasture and the level of humidity from place to another place.

In the present study, the risk of infection to all age groups was the same. The young and adult rabbit had the same risk of infection. Similar risk of infection could be due to the fact that both young and adult rabbit were exposed to the same risk of infection by the infective stage of $P$. ambiguus due to the knowledge about the hygienic measures as kits remain in contact with their dams, as well as might be attributed to the nature of studying area. Additionally, the sex of rabbit was not significantly associated with prevalence of helminths in this study despite the higher frequency in females $(6.4 \%)$ compared with males $(3.8 \%)$. This finding supports with the general understanding of helminth infections that female animals are more susceptible to helminthiasis. It is assumed that sex is a determinant factor influencing prevalence of parasitism (Maqsood et al. 1996) and females are more prone to parasitism during pregnancy and peri-parturient period due to stress and decreased immune status (Urquhart et al. 1996). Moreover, breed was found to be statistically significant as a risk factor, which has a great effect on the prevalence of helminths in examined breeds of rabbits. It seems to be associated with genetic and inheritable effect and to some extent management factors like rearing system. Regarding the distribution of infections according to seasons, a considerable difference was found in the prevalence of $P$. ambiguus among different season, with the highest value found in summer season $16.9 \%$ followed by spring $3.2 \%$, without recorded infection in both winter and autumn seasons. Similarly, farmed rabbits were most often infested by P.ambiguus whose prevalence varied with season of the year, with the highest extensity $40 \%$ in the summer period and the parasite did not occur in autumn season (Nosal et al. 2006; Szkucik 2014). The reason for the higher prevalence during summer could be due to favorable ecological and environmental conditions of the study area. The high temperature and humidity during the summer provides a conducive atmosphere for luxurious growth of infective larvae on pasture.

Regarding to the histopathological results, the naturally infected rabbits with coccidia showed the presence of different developmental stages of Eimeria spp. invaded epithelial cells of the intestine. Furthermore, it had characteristic lesions manifested by severe degree of necrosis of the intestinal cells characterized by pyknotic and tiny nuclei with acidophilic cytoplasm were detected along intestinal tissues. Sloughing with desquamation of the epithelial lining at the lumen was also noted. Moreover, atrophy of intestinal villi was noticed. These findings were similar to the figures previously reported in the intestinal coccidiosis as the lesions were seen in the small and large intestine depending on the causative agent as the parasitized epithelial cells become necrotic, may result in ulceration, which appeared grossly as multiple white areas in the wall of intestine (Yakhchali \& Tehrani 2007).

\section{CONCLUSION}

In conclusion, to the best of the author's knowledge this is the first report of E. piriformis and Cryptosporidium oocyst among studied rabbits in the study region. Additionally, the current study showed the characteristics of the prevalence of rabbit enteric parasite infection in Egypt and provided relevant 'baseline' data for assessing the effectiveness of future control strategies against these parasites in Egypt. Parasitic invasions, especially coccidiosis, have prominent effect on animal overall performance and economic benefits of rabbit production. Furthermore, The present figures indicates that persons handling or otherwise exposed to rabbits are at greater risk of zoonotic infection from Cryptosporidium and thus becoming a source of infection for others, because attention cannot paid to personal hygiene, more extensive studies in rabbits in different areas are needed to better characterize the transmission of cryptosporidiosis and to assess the public health significance of these parasites. 


\section{ACKNOWLEDGEMENTS}

We thank the reviewers for their time to carefully review our manuscript. We believe that their positive comments substantially improved this article. The authors declare that there are no conflicts of interest.

\section{REFERENCES}

Abdel-Baki,A.S. \& Al-Quraishy, S. 2013. Prevalence of Coccidia (Eimeria spp.) infection in Domestic Rabbits, Oryctolagus cuniculus, in Riyadh, Saudi Arabia. Pakistan Journal of Zoology 45(5): 1329-1333.

Abdel-Megeed, K.N., Abuel-Ezz, N.M. \& Abdel-Rahman, E.H. 2005. Protective effect of Eimeria stiedae coproantigen against hepatic coccidiosis in rabbits. Journal of the Egyptian Society of Parasitology 35: 581-595.

Abu-Akkada, S.S., Oda, S.S. \& Ashmawy, K.I. 2010. Garlic and hepatic coccidiosis: Prophylaxis or treatment? Tropical Animal Health and Production 42: 1337-1343. DOI 10.1007/ s11250-010-9590-6.

Al-Mathal, E.M. 2008. Hepatic coccidiosis of the domestic rabbit Oryctolagus cuniculus domesticus L. in Saudi Arabia. World Journal of Zoology 3: 30-35.

Al-Rukibat, R.K., Irizarry, A.R., Lacey, K., Lazacos, K.R., Storandt, S.T. \& Denicola D.B. 2001. Impression smears of liver tissue from a rabbit. Veterinary Clinical Pathology 30: 57-61. DOI: 10.1111/ j.1939-165X.2001.tb00259.x

Angus, K.W., Appleyard, W.T., Menzies, J.D., Campbell, I. \& Sherwood, D. 1982. An outbreak of diarrhoea associated with cryptosporidiosis in naturally reared lambs. Veterinary Record 110(6): 129-130.

Arafa, M.A. \& Wanas, M.Q. 1996. The efficacy of ivermectin in treating rabbits experimentally infected with Eimeria as indicated parasitologically and histologically. Journal of the Egyptian Society of Parasitology 26: 773-780.

Ashmawy, K.I., El-Sokkary, M.Y., Abu-Akkada, S.S. \& Dewair, A.W. 2010. Incidence of Passalurus ambiguus in domestic rabbits in Behera province. Alexandria Journal of Veterinary Sciences 30(1): 115-120.

Atta, A.H., El-Zeni, A. \& Samia, A. 1999. Tissue residues of some sulphonamides in normal and Eimeria stiedae infected rabbits. Deutsche tierärztliche Wochenschrift 106: 295-298.

Bhat, T.K., Jithendran, K.P. \& Kurade, N.P. 1996. Rabbit coccidiosis and its control: A review. World Rabbit Science 4: $37-41$

Bern, C., Ortega, Y., Checkley, W., Roberts, J.M., Lescano, A.G., Cabrera, L., Verastegui, M., Black, R.E., Sterling, C. \& Gilman, R.H. 2002. Epidemiologic differences between cyclo-sporiasis and cryptosporiasis in Peruvian children. Emerging Infectious Diseases 8: 581-585.

Biu, A.A. \& Nwosu, C.O. 1998. Prevalence of gastro-intestinal parasites of rabbits in an arid zone of Nigeria. Annals of Borneo 15/16: 356-358.

Boag, B. 1985. The incidence of helminth parasites from the wild rabbit Oryctolagus cuniculus (L.) in Eastern Scotland. Journal of Helminthology 59: 61-69.

Carlton, W. \& McGavin, M.D. 1995. Thompson's Special Veterinary Pathology. 2nd ed., Mosby, St. Louis. pp. 46-47.

Carvalho, F.S., Wenceslau, A.A., Teixeira, M., Matos, J.A., Melo, A.D. \& Albuquerque G.R. 2011. Diagnosis of Eimeria species using traditional and molecular methods in field studies. Veterinary Parasitology 176: 95-100. DOI: 10.1016/j. vetpar.2010.11.015.
Chalmers, R.M., Robinson, G., Elwin, K., Hadfield, S.J., Xiao, L., Ryan, U., Modha, D. \& Mallaghan, C. 2009. Cryptosporidium rabbit genotype, a newly identified human pathogen. Emerging Infectious Diseases 15: 829-830. DOI: 10.3201/eid1505.081419.

Chandra, D. \& Ghosh, S.S. 1990. Incidence of diarrhoel infections in rabbits. Indian Journal of Animal Sciences 60: 801-803.

Coudert, P., Licois, D. \& Drouet-Viard, F. 1995. Eimeria species and strains of rabbit. In Biotechnology: Guidelines on techniques in Coccidiosis Research, edited by Eckert, J., Braun, R., Shirley, M.W. \& Coudert, P. COST. 89/820. Office for Official Publications of the European Communities, Luxembourg. pp. 52-73.

De Graaf, D.C., Vanopdenbosch, E., Ortega-Mora, L.M., Abbassi, H. \& Peeters, J. 1999. A review of the importance of cryptosporidiosis in farm animals. International Journal for Parasitology 29: 1269-1287.

Eira, C., Torres, J., Miquel, J. \& Vingada, J. 2007. The helminth parasites of the wild rabbit Oryctolagus cuniculus and their effect on host condition in Dunas de Mira, Portugal. Journal of Helminthology 81(3): 239-246. DOI: 10.1017/ S0022149X07727426.

El-Shahawi, G.A., El-Fayomi, H. \& Abdel-Haleem, H.M. 2012. Coccidiosis of domestic rabbit (Oryctolagus cuniculus) in Egypt: Light microscopic study. Parasitology Research 110: 251-258. DOI: 10.1007/s 00436-011-2479-0.

Gonzalez-Redondo, P., Finzi, A., Negretti, P. \& Micci, M. 2008. Incidence of coccidiosis in different rabbit keeping systems. Arquivo Brasileiro de Medicina Veterinária e Zootecnia 60: 1267-1270.

Gres, V., Voza, T., Chabaud, A. \& Landau, L. 2003. Coccidiosis of the wild rabbit (Oryctolagus cuniculus) in France. Parasite 10: $51-57$

Gurpartap, S. \& Khahra, S.S. 1997. Incidence of rabbit coccidia in Punjab state. Journal of Veterinary Parasitology 11(1): 7-10.

Hansen, J. \& Perry, B. 1994. The Epidemiology, Diagnosis and Control of Helminth 6 Parasites of Ruminants. A Handbook 2nd ed. Nairobi, Kenya: ILRAD (International Laboratory for 7 Research on Animal Diseases). p. 171.

Harcourt, B.F. 2002. Textbook of Rabbit Medicine Educational and Professional Publishing Ltd. Oxford, UK.

Henriksen, S.A. \& Pholenz, J.F.L. 1981. Staining of Cryptosporidium by a modified Zheil-Neelson technique. Acta Veterinaria Scandinavica 22: 594-596.

Karaer, Z. 2001. Evcil Tavşanlarda (Oryctolagus cuniculus) Coccidiosis. In Coccidiosis. Türkiye Parazitoloji Derneği Yayınları, edited by Dinçer, Ş. No.17. Meta Basım, İzmir. pp. 269-278.

Kvičerová, J., Pakandl, M. \& Hypša, V. 2008. Phylogenetic relationships among Eimeria spp. (Apicomplexa, Eimeriidae) infecting rabbits: Evolutionary significance of biological and morphological features. Parasitology 135: 443-452. DOI: 10.1017/ S00311 82007004106.

Lebdah, M.A. \& Shahn, A.M. 2011. Closteridia as an etiological agent of mucoid enteropathy in rabbits. Natural Science 9 : 63-72.

Li, M., Huang, H. \& Ooi, H. 2010. Prevalence, infectivity and oocyst sporulation time of rabbit-coccidia in Taiwan. Tropical Biomedicine 27(3): 424-429.

Li, M.H. \& Ooi, H.K. 2009. Faecal occult blood manifestation of intestinal Eimeria spp. infection in rabbit. Veterinary Parasitology 161: 327-329. DOI: 10.1016/ j. vetpar. 2009.01.009. 
Maqsood, M., Igbai, Z. \& Chaudhry, A.H. 1996. Prevalence and intensity of haemonchosis with reference to breed, sex and age of sheep and goats. Pakistan Veterinary Journal 16: 41-43.

Molloy, S.F., Smith, H.V., Kirwan, P., Nichols, R.A., Asaolu, S.O., Connelly, L. \& Holland, C.V. 2010. Identification of a high diversity of Cryptosporidium species genotypes and subtypes in a pediatric population in Nigeria. American Journal of Tropical Medicine and Hygiene 82: 608-613. Doi: 10.4269/ ajtmh.2010.09-0624.

Morgan, U.M., Buddle, J.R., Armson, A., Elliot, A. \& Thompson, R.C. 1999. Molecular and biological characterisation of Cryptosporidium in pigs. Australian Veterinary Journal 77: 44-47.

Nosal, P., Petryszak, A., Nowosad, B. \& Sobolewska, M. 2006. Gastrointestinal parasites of rabbits in coproscopic investigations. Wiadomości Parazytologiczne 52: 327-330.

Nwosu, C.O., Madu, P.P. \& Richards, W.S. 2007. Prevalence and seasonal changes in the population of gastrointestinal nematodes of small ruminants in the semi-arid zone of NorthEastern Nigeria. Veterinary Parasitology 144: 118-124.

Ohaeri, C.C. \& Iwu, C.J. 2003. Prevalence of Cryptosporidium species in some domestic animals in Abia State, Nigeria. Journal of Sustainable Agriculture and the Environment 5: 309-312.

Pakandl, M., Hlaskova, L., Poplstein, M., Chroma, V., Vodicka, T., Salat, J. \& Mucksova, J. 2008. Dependence of the immune response to coccidiosis on the age of rabbit suckling. Parasitology Research 103: 1265-1271. DOI: 10.1007/ s00436-008-1123-0.

Rajkhowa, C. 1996. Incidence of rabbit coccidiosis in Meghalaya and its control. Journal of Veterinary Parasitology 10: 175178.

Razavi, S.M., Oryan, A., Rakhshandehroo, E., Moshiri, A. \& Mootabi, A. 2010. Eimeria species in wild rabbits (Oryctolagus cuniculus) in Fars province, Iran. Tropical Biomedicine 27: 470-475.

Renaux, S., Quéré, P., Buzoni-Gatel, D., Sewald, B., Le Vern, Y., Coudert, P. \& Drouet-Viard, F. 2003. Dynamics and responsiveness of T-lymphocytes in secondary lymphoid organs of rabbits developing immunity to Eimeria intestinalis. Veterinary Parasitology 110: 181-195. DOI: 10.1016/ S0 304- 4017(02)00305-9.

Robinson, G., Elwin, K. \& Chalmers, R.M. 2008. Unusual Cryptosporidium genotypes in human cases of diarrhea. Emerging Infectious Diseases 14: 1800-1802. DOI: 10.3201/ eid1411.080239.
Shameem, H. \& Devada, K. 2005. Prevalence of rabbit coccidiosis in Thrissur. Journal of Veterinary Parasitology 19(1): 69-70.

Shiibashi, T., Imai, T., Sato, Y., Abe, N., Yukawa, M. \&. Nogami, S. 2006. Cryptosporidium infection in juvenile pet rabbits. Journal of Veterinary Medical Science 68(3): 281-282.

Sivajothi, S., Reddy, S. \& Rayulu, V.C. 2014. Study on impression smears of hepatic coccidiosis in rabbits. Journal of Parasitic Diseases 40(3): 906-909. DOI 10.1007/ s12639-014-0602-8.

Soulsby, E.J.L. 1986. Textbook of Helminths, Arthropods and Protozoa of Domesticated Animals. 7th edition. London: The English Language Book Society and Bailliere Tindall.

Sürsal, N., Gökpinar, S. \& Yildiz, K. 2014. Prevalence of intestinal parasites in hamsters and rabbits in some pet shops of Turkey. Türkiye Parazitoloji Dergisi 38: 102-105. DOI: 10.5152 / tpd. 2014.3338.

Szkucik, K., Pyz-Łukasik, R., Szczepaniak, K.O. \& Paszkiewicz, W. 2014. Occurrence of gastrointestinal parasites in slaughter rabbits. Parasitology Research 113: 59-64. DOI: 10.1007/ s00436-013-3625-7.

Tae-Wook, P., Won, S., Chong-Sung, K. \& Hong-Ji, Y. 2003. Survey on the prevalence of parasites in rabbit of Jeonbuk area. Korean Journal of Veterinary Service 26(1): 33-37.

Urquhart, G.M., Armour, J., Duncan, J.L., Dunn, A.M. \& Jennings, F.W. 1996. Veterinary Parasitology. 2nd ed. Oxford: Blackwell Science Ltd. pp. 224-234.

Yakhchali, M. \& Tehrani, A.A. 2007. Eimeriosis and pathological findings in New Zealand white rabbits. Pakistan Journal of Biological Sciences 7: 1488-1491.

Ismail Elshahawy*

Department of Parasitology

Faculty of Veterinary Medicine

South Valley University

Egypt

\section{Ashraf Elgoniemy}

Department of Pharmacology

Faculty of Veterinary Medicine

South Valley University

Egypt

*Corresponding author; email: dr.ismail_para@yahoo.com

Received: 14 December 2016

Accepted: 3 September 2017 